\title{
Concentration of electrolytes in the sweat of malnourished children
}

\author{
Mary Elisabeth S M Rodrigues, Maria do Carmo B Melo, Francisco J C Reis, \\ Francisco J Penna
}

\begin{abstract}
The sweat test was performed by the method of Gibson and Cooke on 36 children with second and third degree malnutrition, aged from 2 months to 4 years. The results were compared with those from 32 healthy, well nourished controls in the same age range. Determinations were made of sodium and chloride concentrations, chloride/sodium ratio, and the sum of the concentrations of the two electrolytes in each sample.

The malnourished children were found to have higher sodium and chloride concentrations than the well nourished ones. None of the normal or malnourished children had a sweat chloride value greater than $60 \mathrm{mmol} / 1$; chloride values within a suspicious range (between 40 and $60 \mathrm{mmol} / \mathrm{l}$ ) were found in two malnourished children. Two well nourished controls and six malnourished children showed suspicious sweat sodium concentrations; in one child with third degree malnutrition the sodium content was greater than $60 \mathrm{mmol} / 1$. In all results in the suspicious range, or greater than 60 $\mathrm{mmol} /$, the chloride/sodium ratio was less than 1 , and the sum of the two electrolytes was below $140 \mathrm{mmol} / 1$.

Based on these results, we conclude that malnourished children have raised sweat sodium and chloride concentrations when compared with well nourished children. The electrolyte values for most of them are not in a suspicious range or consistent with a diagnosis of cystic fibrosis. Unlike that found in cystic fibrosis, the sodium/chloride ratio in our subjects was less than 1 and the sum of both electrolytes never exceeded $140 \mathrm{mmol} /$. (Arch Dis Child 1994; 71: 141-143)
\end{abstract}

Paediatrics, Hospital das Clínicas, Federal University of Minas Gerais, Belo Horizonte, Brazil M E S M Rodrigues $M$ do C B Melo

F J C Reis

F J Penna

Correspondence to: Dr Mary Elisabeth Santos Moura Rodrigues, Departamento de Pediatria, Faculdade de Medicina, Universidade Federal de Minas Gerais, Avenida Alfredo Balena, no 190, Belo Horizonte, Minas Gerais, Accepted 1 March 1994 digestive and respiratory manifestations associated with an altered sweat test, it may be difficult to rule out or to confirm the diagnosis of cystic fibrosis in patients with protein energy
A raised concentration of sodium and chloride problems. Digestive symptoms as well as recurrent respiratory tract infections are also frequently observed in patients with primary malnutrition. Protein energy malnutrition is quoted in the literature as a cause of raised ${ }^{2-4}$ or low ${ }^{5}$ concentrations of sweat electrolytes. The present study was undertaken with the purpose of clarifying this. In addition to comparing the chloride and sodium concentrations of the two groups - well nourished and malnourished children - an analysis was done of the chloride/sodium ratio and of the sum of the two electrolytes in each sweat sample. The concentration of chloride in the sweat of patients with cystic fibrosis is normally greater than that of sodium, and the sum of the two electrolytes in each sample usually exceeds 140 $\mathrm{mmol} /{ }^{6}{ }^{6}$

\section{Subjects and methods}

The sample for this cross sectional study consisted of two groups of children, classified with regard to their nutritional status by the method of Gómez et al. ${ }^{7}$

Group 1 consisted of 32 healthy children seen during routine examinations in outpatient clinics of the Hospital das Clínicas, Federal University of Minas Gerais. Their ages ranged from 3 months to 3.7 years (mean (SD) 1.7 $(1 \cdot 1)$ years). Eighteen (56\%) were boys and 14 $(44 \%)$ girls; 13 (41\%) children were white and $19(59 \%)$ non-white. The weight and height of all children in this group were greater than the 10 th centile.

Group 2 consisted of 36 children who suffered from second and third degree primary protein energy malnutrition. Their age, sex, and race were comparable with those of group 1 with age ranging from 2 months to $4 \cdot 0$ years (mean (SD) $1 \cdot 1(1 \cdot 0)$ years). Thirteen $(36 \%)$ were girls and $23(64 \%)$ non-white. The children in this group were taking part in a nutritional recovery programme undertaken by public hospitals. All patients in this group had at least one of the signs of protein energy malnutrition: reduced subcutaneous tissue, muscular hypotrophy, skin lesions, hair dyspigmentation, or muscle tone alterations. One infant had oedema. Clinical history and physical examination revealed no signs or symptoms of diseases other than malnutrition. The weight of all children in this group was below the 3rd centile and their height was below the 10th centile.

The following exclusion criteria were used: chronic diarrhoea, chronic or recurrent lung disease, dehydration, fever, acute disease of any nature, those receiving venous or oral hydration, family history of cystic fibrosis, or signs or symptoms of any other diseases known 
to cause raised sweat electrolyte concentrations.

\section{SWEAT TEST}

The sweat test was carried out by the method of Gibson and Cooke, ${ }^{8}$ which consists of three phases: (1) induction of sweating by pilocarpine iontophoresis for 30 to 60 seconds using $70 \mathrm{~cm}$ quantitative No 3 Whatman filter paper containing $0.06 \%$ ashes and measuring 3 $\mathrm{cm}$ in diameter; (2) elution of filter paper in 5 $\mathrm{ml}$ deionised water for at least 24 hours; the eluate was placed in a flask that was tightly sealed and stored in the refrigerator until the time for biochemical measurements; (3) biochemical electrolyte measurement: chloride was estimated by the method of Schales and Schales. ${ }^{9}$ Sodium was determined using a flame photometer (Micronal B262 - sensitivity II).

As it was impossible to collect two sweat samples from each child on different days, two samples were collected on same day, one from each forearm. A pilot study was carried out before the present investigation to compare electrolyte concentration of sweat from the right arm and the left arm, showing that there was no statistically significant differences in chloride or sodium concentration between sweat samples from the right and left arms. The mean (SD) chloride concentration of the right arm was $13.3(6.2) \mathrm{mmol} / \mathrm{l}$ and the left arm $14.0(6.9) \mathrm{mmol} / \mathrm{l} ; \mathrm{p}=0.51$. The mean (SD) sodium concentration of the right arm was $28.9(9.3) \mathrm{mmol} / \mathrm{l}$ and the left arm 27.9 $(9 \cdot 2) \mathrm{mmol} / \mathrm{l} ; \mathrm{p}=0.55$.

Only children whose parents, after a careful explanation of the procedure, had read and signed the terms of permission were included in the study.

We used the Student's $t$ test for comparing two independent means.

\section{Results}

The table shows the means of right and left arm concentrations of chloride and sodium concentrations in the two groups. The malnourished children had a higher concentration of sweat chloride and sodium than the well nourished group, the difference being statistically significant. In the comparison between the subgroups of malnourished children (second and third degree), no statistically significant difference was found.

An analysis was done of the frequency of children in each group with results in the suspicious range - between 40 and $60 \mathrm{mmol} / 1$ - or greater than $60 \mathrm{mmol} / \mathrm{l}$. None of the well nourished children had a chloride concentration

Mean (SD) chloride and sodium concentrations in the sweat of well nourished and malnourished children

\begin{tabular}{|c|c|c|c|c|}
\hline & \multirow{2}{*}{$\begin{array}{l}\text { Well nourished } \\
\text { (group } 1) \\
(n=32)\end{array}$} & \multirow{2}{*}{$\begin{array}{l}\text { Malnourished } \\
\text { (group 2) } \\
(n=36)\end{array}$} & \multicolumn{2}{|c|}{ Statistics } \\
\hline & & & $\mathbf{t}$ & $p$ \\
\hline $\begin{array}{l}\text { Chloride }(\mathrm{mmol} / \mathrm{l}) \\
\text { Sodium }(\mathrm{mmol} / \mathrm{)}\end{array}$ & $\begin{array}{l}11 \cdot 7(4 \cdot 5) \\
24 \cdot 8(7 \cdot 3)\end{array}$ & $\begin{array}{l}15 \cdot 4(7 \cdot 0) \\
31 \cdot 6(9 \cdot 1)\end{array}$ & $\begin{array}{l}-2 \cdot 67 \\
-3 \cdot 43\end{array}$ & $\begin{array}{l}0.010 \\
0.001\end{array}$ \\
\hline
\end{tabular}

above $60 \mathrm{mmol} / 1$, yet suspicious sodium values were found for two of them. In the malnourished, one child had a chloride value between 40 and $60 \mathrm{mmol} / \mathrm{l}$, and six had sodium concentrations higher than $60 \mathrm{mmol} / 1$. In all determinations, chloride was lower than sodium, and the sum of the two electrolytes in each was below $140 \mathrm{mmol} / \mathrm{l}$.

The chloride/sodium ration of the two groups was also compared. Comparable results for this variable were found for the two groups and the chloride/sodium ratio was less than 1 in most determinations.

\section{Discussion}

CLASSIFICATION OF THE NUTRITIONAL STATUS

Nutritional status was determined by the criterion of Gómez et al. ${ }^{7}$ This has been criticised as it considers only the child's weight and can be particularly faulty when children with mild malnutrition or older than 4 years are evaluated. Children with mild malnutrition were excluded from our study, and the age range for our groups was 2 months to 4.0 years (group 2) and 3 months to $3 \cdot 7$ years (group 1). Also, data such as patient weight and height centiles, clinical history, socioeconomic and alimentary history, and physical examination were used to support the classification of the nutritional status of our subjects.

\section{RELIABILITY OF THE SWEAT TEST}

The reliability of the results obtained was based on the extensive experience of the clinic where the study was undertaken. Over a period of eight years, 2052 sweat tests were performed in the clinic on children suspected of having cystic fibrosis. Also supporting the reliability of the results were: (1) the correlation between sodium and chloride concentrations ${ }^{1} 810$ which in all tests was less than $30 \mathrm{mmol} / \mathrm{l}$; (2) the analysis of two sweat samples from each patient; and (3) the exclusion of samples weighing less than $100 \mathrm{mg}$. All samples used exceeded $100 \mathrm{mg}$.

\section{RESULTS OF THE SWEAT TEST}

The sweat of children with primary protein energy malnutrition of the second and third degree was found to contain higher mean concentrations of chloride and sodium than that of well nourished children. However, the mean value for both electrolytes was less than that considered suspicious or consistent with the diagnosis of cystic fibrosis. Analysis of the results in the suspicious range or greater than $60 \mathrm{mmol} / \mathrm{l}$ showed that, unlike that reported for patients with cystic fibrosis, chloride concentrations were lower than sodium concentrations, and the sum of the two electrolytes in each sample was less than $140 \mathrm{mmol} / \mathrm{l}$. These results do not agree with those obtained by other authors. Sénecal and Dan analysed sweat test results for children with third degree malnutrition and found that the children with kwashiorkor had a lower chloride concentration. ${ }^{5}$ This was even lower in children with 
marasmus-type malnutrition when compared with well nourished controls. McCance et al, also studying kwashiorkor and marasmus, observed no difference in sweat chloride concentrations between patients with these two types of malnutrition and well nourished controls. ${ }^{10}$ In Brazil, Benchimol compared the results of the sweat test on patients with first, second, and third degree malnutrition. ${ }^{4}$ Malnutrition did not lead to raised sweat chloride or sodium concentrations such as would be likely to affect the value of the sweat test for the diagnosis of cystic fibrosis. They found the chloride concentration, but not the sodium concentration, was greater for the malnourished patients. These discrepancies could be explained by the different methods used in the various studies.

The statement that malnutrition is a frequent cause of raised sweat electrolyte concentrations is due to the studies undertaken by Beck et al, ${ }^{11}$ Mace, ${ }^{12}$ and Ruddy and Scalin. ${ }^{13}$ Those were retrospective studies or case studies with no control group and with estimation of only one electrolyte. They used a different methodology from the one used in our study. These factors could explain the conflicting results.

\section{CONCLUSION}

The children with protein energy malnutrition of the second and third degree by the classification of Gomez et al showed higher chloride and sodium concentrations in sweat than the well nourished controls. However, in most of the children the values observed were below the range considered suspicious or consistent with the diagnosis of cystic fibrosis. Analysis of the chloride/sodium ratio and the sum of the two electrolytes in each sample showed that the malnourished children behaved in a different way from children with cystic fibrosis. In patients with cystic fibrosis the chloride/ sodium ratio is greater than 1 and the sum of the electrolytes exceeds $140 \mathrm{mmol} / 1$. In this study, the reverse was observed for the malnourished children.

On the basis of the present results, we conclude that using the estimation of sweat electrolytes malnourished children without cystic fibrosis can be distinguished from children with cystic fibrosis.

We thank Professor Dr Eugênio Marcos A Goulart for his collaboration on statistical analysis.

1 Committee for a study for evaluation of testing for cystic fibrosis. F Pediatr 1976; 88: 711-50.

2 Doershuck CF, Boat TF. Cystic fibrosis. In: Behrman R, Vaughan VC, Nelson WE, eds. Nelson textbook of pediatrics. 13th Ed. Philadelphia: WB Saunders, 1987: 926-35.

3 Maclusky I, Levison H. Cystic fibrosis. In: Chernick V, ed. Kendig's disorders of the respiratory tract in children. 5th Ed. Pendig's disorders of the respiratory tract in childrer

4 Benchimol JA. Teste do suor pelo método da iontoforese com pilocarpina; resultados obtidos nas crianças com desnutrição protéico-calórica. Hiléia Médica 1980; 2: $71-133$.

5 Sénecal I, Dan V. The sweat test in children with malnutrition. Turk f Pediatr 1963; 5: 31-41.

6 Green A, Dodds P, Pennock C. A study of sweat sodium and chloride criteria for diagnosis of cystic fibrosis. Ann Clin Biochem 1985; 22: 171-4.

7 Gómez F, Galvan RR, Frank S, Cravioto M, Chavez R, Vasquez J. Mortality in second and third degree malnutrition. $\mathcal{F}$ Trop Pediatr 1956; 2: 77-83.

8 Gibson LE, Cooke RE. A test for concentration of electrolytes in sweat in cystic fibrosis of the pancreas electrolytes in sweat in cystic fibrosis of the pancreas
utilizing pilocarpine by iontophoresis. Pediatrics 1959; 23: $545-9$.

9 Schales O, Schales SS. A simple and accurate method for the determination of chloride in biological fluids. $f$ Biol Chem 1941; 140: 879-84.

10 McCance RA, Rutishauser IHE, Knight HC. Response of sweat glands to pilocarpine in the Bantu of Uganda. Lancet 1968; i: 663-5.

11 Beck R, Durie PR, Hill IG, Levison H. Malnutrition: a cause of elevated sweat chloride concentration. Acta Paediatr Scand 1986; 75: 639-44.

12 Mace JW, Schanberger JE. Elevated sweat chlorides in a child with malnutrition. Clin Pediatr (Phila) 1971; 10: 285-6.

13 Ruddy RM, Scalin TF. Abnormal sweat electrolytes in a case of celiac disease and a case of phychosocial failure to thrive: review of other reported causes. Clin Pediatr (Phila) 1987; 26: 83-9. 